DOI: $10.32743 /$ dictum-factum.2020.23-31

\title{
Economic Lexicon in Mass Media Texts: Linguocultural Aspect
}

\author{
Nadezhda BONDAREVA \\ Senior Lecturer \\ English Language Department \\ Admiral Ushakov Maritime State University, Sevastopol Branch \\ 8/22, 11, Geroev-Sevastopolja str., Sevastopol, 299009, the Russian Federation \\ +7 (8692) 48-74-39 \\ bonnadin@yandex.ru
}

\begin{abstract}
The paper addresses properties of economic vocabulary in modern mass media text. Interaction between texts types of the media discourse and the status of economic vocabulary units is established. The author describes functioning and specific features of economic vocabulary in texts of news, on-line articles and advertisements. A certain range of addressees, theme peculiarities and functions determine lexical and semantic originality of the texts of economic news, on-line articles, and advertisements. The main function of news is informative function. Therefore, the main lexical units are denotative elements of semantics: economic terms and economic realias. The author describes three functions of media discourse: informative, evaluating, and suggestive. Different recipients, subject features, and predominance of one of the functions determine lexical and semantic originality of the mass media article. One of the main functions of the advertisement is impact function. According to this function there are economic symbols, concepts, and different stylistic devices in the texts of economic advertisements. Lexical units used in English and Russian economic media texts have common features as well as specific national peculiarities.
\end{abstract}

Keywords: media text; economic lexicon; news; advertisement; online-article; linguoculture; function.

\section{Introduction}

There is a growing need of new means for ensuring the effectiveness of intercultural contacts in the modern world. The components of different cultures combine in the people's mind and spontaneous media centers for the perception of cultural information, including in the sphere of economy, are created (Zheltukhina, 2014). Phenomena occurring in the economy are reflected in the language; 
thus, new terms and concepts appear. These terms and concepts affect the development of the media language.

Economic media texts affect economic processes and economic situation in the country and in the world. Texts of news, advertisements, and online articles may be apprehended differently depending on the lexical units used in them. "The mass media texts not just display the surrounding reality and record the events happening around them objectively. They affect all socio-political processes in society directly or indirectly, clearly or in a hidden form" (Dobrosklonskaya, 2008).

The subject of our analysis is the lexis of economics. As we know, economics is on the border between technical and social sciences. Economics is characterized by mathematical precision and clarity on the one hand, but on the other hand the main object of Economics is the relationship between people. This determines the significant influence of the human factor on the conceptual apparatus of various branches of the economic science. As to linguistic level all said above determine the expression of economic vocabulary, the presence of numerous paradigmatic connections (polysemic, synonymous, homonymous, etc.).

The objective of the research is analysis of the features of English and Russian economic vocabulary in the texts of the media discourse. The objective of the research defines its problems: 1 ) to consider the functional aspect of English and Russian economic vocabulary in media texts; 2) to determine the linguistic and cultural specificity of the economic vocabulary in the above-mentioned texts; 3) to identify common features and differences in the representation of economic vocabulary in mass media texts in two cultures.

\section{Methods}

The theoretical base of our research is formed by works of many Russian and foreign scientists in the field of cognitive linguistics, pragmalinguistics, socio- and psycholinguistics, discourse linguistics, cultural linguistics, intercultural communication (Dobrosklonskaya, 2005; Zheltukhina, 2014; Zelenskaya et al., 2018; Tameryan, Zheltukhina, Slyshkin, Abakumova, Volskaya, Nikolaeva, 2018; Chilton, 2004; Dijk, 1997; Franssila, 2013; Jamieson, Campbell, 1997).

The complex methods are used in the research: analysis of definitions, lexical analysis, semantic analysis, descriptive analysis, comparative analysis, stylistic and emotive analysis of the realization of the economic vocabulary in the media discourse. The ways of analysis are useful for development of cognitive linguistics, socio-and psycholinguistics, semantics, pragmatics, lexicology, stylistics, and discourse linguistics. Texts of news, advertisements and online economic articles were used for obtaining objective data. 


\section{Results}

According to Kazak (2011), the main categories of media text are: media (the realization of the text with the help of media means, the determination of the text using format and technical capabilities of the channel), mass (large-scale participation in the area of creation and consumption of media products), text integration or multikey (combing of different semiotic codes into the comprehensive unit), transparency of the text.

The texts of news are considered the basic texts of the media, since the main function of mass communication (the transmission of information) is most fully realized in these texts. A wide range of people read or listen texts of news, therefore common vocabulary is mostly used in theses texts. At the same time news reporting about major business and financial events contain special terminological lexical units.

The following lexical units are widely used in the media economic texts of news:

- economic terms (bond, stock exchange, profitability, dividends, devaluation, inflation);

- abbreviations and acronyms (WTO, FIU, NATO (North Atlantic Treaty Organisation), GDP (gross domestic product), FOREX (foreign exchange market);

- the names of various organizations, companies (PJSC "LUKOIL", OJSC "Surgutneftegas", Rolls Royce, Knightsbridge Furniture, Loblow Companies Limited).

Moreover the news may include terms and abbreviations that have not yet been recorded in dictionary entries. For example, cryptocurrency (digital money that exists only in the form of virtual coins and is created in the network without the participation of real money); ICO (Initial coin offering - a form of attracting investment in the form of selling a fixed number of new cryptocurrency units to investors).

The lexical composition of the news texts with the economic orientation is also characterized by the presence of economic realias which denote phenomena characteristic of a particular culture. "The national and cultural contents in these words are the core of their meaning, and they denote concepts that have no analogues in our economic reality" (Bakasheva, 2016). Such lexical elements reflect the features of the economy of a particular country in a particular time period most clearly:

челночный бизнес - business of petty traders who regularly go abroad to buy saleable goods, "shuttle business";

мавродики, мавробаксы - securities of phony joint stock company MMM, "Mavrodiki", "mavrobaksy"; 
"junk-bond" - high-yield bonds with a credit rating below the investment grade or without a rating;

"blocked units" -shares that were issued to employees of the company as the remuneration for their work ;

"market eye" - financial information service of the British broadcasting company.

The texts of news use evaluative and figurative vocabulary: black cash, outsider, sluggish economy, smart money, a weak ruble. At the same time media vocabulary with positive emotional stylistic nuance is less common (22\%) than media vocabulary with negative stylistic nuance (47\%). This can be explained by the fact that negative information in the news is more interesting than positive information for the reader/listener. Therefore, vocabulary with a negative emotional colouring is more likely to attract the attention of the audience. It should be noted that vocabulary containing different figures of speech is used more often in English news than in Russian news.

The main differences between English and Russian vocabulary used in news texts are:

- frequent use of neologisms in English information texts: money-man, laggard, business-tobusiness, e-trade;

- the migration of the special field terms into media news, i.e. the transition of the term from one sphere of usage to another ones, is quite frequent phenomenon in English information texts: recruiting, free-fall;

- a large number of Anglicisms and Americanisms in texts of Russian news: консалтинг (from English “consulting”), медиахолдинг (from English "mediaholding”), офф-шор (from English "off-shore"), маркетинг (from English "marketing”).

As it was mentioned above, the main function of news is informative. This function is not the only one in online articles. Such functions as evaluation and suggestive functions are also present in economic articles. "Most of the online articles contain the author's attitude to the described events. Thus, the evaluation function is shown in such texts. The suggestive function is implemented by the fact that almost any online economic article contains an explicit or implicit call to perform actions, i.e. these texts are the ways of forming public opinion, persuasion, and agitation" (Bondareva, 2016). Of course, an economic article communicates information about certain economic events, such as the state of the market, the national and world economy, international trade, etc. But all this information in a media economic article should be available to a wide range of readers, so highly specialized economic terms are used in such articles quite rarely. In this connection the media vocabulary used in economic mass media articles is mostly common. Economic terms are present in 
articles of this type, but they are terms of broad semantics and it is not difficult to understand them: investment, profit, global economy, monetary and fiscal policy.

Also, it should be noted that the thematic specificity, a wide range of recipients, and functional features of the economic mass media article determine its lexical and semantic originality. "When the online article covers particular themes, such factors as universal interest, entertainment, and individual author's approach are put in the forefront" (Dobrosklonskaya, 2005). Due to these factors such lexical units as realias are used in economic online articles:

new Russians - newly rich business class who made their fortune in the 1990s in post-Soviet Russia (in Russian articles);

"shuttle" business - "shuttle" trade emerged in the late 1980's in Russia and former Soviet Republics as an illegual business; a business of petty traders who regularly go abroad to buy saleable goods (in Russian articles);

blue chips - (of a company) considered to be a safe investment for your money because it is well-established and has performed well in the past (in English articles);

sweatshop production - a small factory where workers are paid very little and work many hours in very bad conditions(in English articles).

Realias used in online articles provide information about the economic, national, and cultural characteristics of a country in a given period of time. Their cultural specificity should be taken into account when working with economic articles or translating them.

Speaking about the main differences in the vocabulary of Russian and English online economic articles, we should note the following:

- there is a large number of English loanwords in Russian economic online articles: liquidity, futures contract, leasing, carsharing;

- there is a large number of stylistically colored neologisms in Russian online articles. These neologisms have appeared from English by means of loan translation: launder money, black market, real estate bubble;

- presence of neologisms in English articles: average, PR manager, consulting, Brexit;

- phraseological units and metaphors occur in English economic online articles more often than in Russian economic online articles. With the help of these phraseological units and metaphors the suggestive function of such texts is put into effect: roller-coaster stock market, a fragile global economy, golden parachute. 


\section{Discussion}

When we speak about economic texts of mass media we should mention advertisement, because advertising is one of the business components. The influence on the people's mind is one of the main functions of advertisements. "The function of influence can be defined as a combination of emotional function (causes a certain emotional reaction, motivates), aesthetic function (the influence of the advertisement as an artwork, where the form of address itself plays an important role), and persuasive function" (Dolzhikova, 2009). "The main characteristics of the advertisement are expressiveness, imperativeness and language compression. All these advertisement properties together with the language economy contribute to the implementation of a suggestive effect on the emotions and feelings of the recipient, which helps to achieve the maximum effect" (Bondareva, Zheltukhina, Zelenskaya, 2019).

The advertisement is intended for a wide range of recipients, Therefore, the main type of vocabulary used in these texts is the common vocabulary. However, sometimes the terms are used even in advertising texts: mortgage, clearing, dividends; leasing, credit score. The frequency of economic terms usage in specialized media advertisement texts aimed at the target audience is $78 \%$ in English and $76 \%$ in Russian advertising media discourse. "The usage of terms helps to form a specific and clear idea of a product or service in the consumer's mind. This increases its sales appeal" (Bondareva, 2015). In advertising media texts of both linguistic cultures, attribute phrases and stylistic techniques are actively used. Due to this the advertised object gets the desired positive emotional colouring and attractiveness. At the same time, it should be noted that there are no economic lexical units with negative connotation in advertisements in both linguistic cultures. We analyzed more than 200 examples of English and Russian advertising texts, and none of them contained economic lexemes with negative evaluation semantics.

There are economic symbols and economic linguistic and cultural concepts in English and Russian advertising texts: "Take money cheap!" (Uniastrum Bank); "Only the Ural worker knows: the cheaper the credit - the less work" (Bank "The Ring of the Urals") (advertisements of Russian banks); "Hard way, dedication, character - it's the way we do business...the American way" (American National Bank).

The given examples show the difference between attitude to money of Americans and Russians: Russians are waiting for a miracle and "easy money", while for Americans the process of earning money is a labor, the American mentality is characterized by greater business efficiency and enterprise (Bondareva, 2015).

\section{Conclusion}


In conclusion we can say the following:

1) The media lexis in English and Russian economic texts has both integral features and differential cultural components. In the aspect of intercultural communication if such cultural features are represented in media texts they may be misunderstood and, as a result, the entire advertising text may not be understood.

2) Anglicisms and Americanisms are the linguistic and cultural peculiarities of Russian economic media lexis of news. English news texts use their own neologisms. The migration of the special field terms into media news and a lot of figurative lexical units are also special features of English news texts.

3) Working with economic online articles you should pay attention to the non-equivalent lexis that gives these texts a national character. If this type of lexical units is not understood, it will be difficult to understand the meaning of the entire online economic article. The phraseological units and metaphors are the means of the pragmatic function implementation in economic online articles. Moreover, it should be added that there are more phraseological units and metaphors in English texts than in Russian ones.

4) The specific cultural components of media lexis in economic texts of advertisements include the use of economic symbols and economic cultural concepts that determine the linguistic and cultural specificity of such texts.

\section{Acknowledgements}

The publication has been prepared with the support of the Russian Conference of young scientists "DICTUM-FACTUM: from research to strategic solutions" (Sevastopol, SevSU, 5-6. December 2019).

\section{References}

Bakasheva, N.S. (2016). To the problem of non-equivalent vocabulary translation. Actual Questions of Philological Sciences: Proceedings of the IV International Conference. Kazan, 61-64. Retrieved from: https://moluch.ru/conf/phil/archive/232/10965

Bondareva, N.V. (2015). Economic Lexicon in Media Genres of "News" and "Advertising" (Based on Material of English and Russian Media Discourse). Lomonosov Moscow State University Bulletin. Philology, Culturology, Pedagogy, Methodology, 69-75.

Bondareva, N.V. (2016). Functions of Economic Vocabulary in the Modern English and Russian Media Advertisement. Bulletin of Volgograd State Pedagogical University, 2, 78-83. 
Bondareva, N.V., Zheltukhina, M.R., Zelenskaya, L.L. (2019). Economic Lexicon in Online Articles of Social and Economic Orientation (on the Examples of English and Russian Media Discourse). Current Issues in Philology and Pedagogical Linguistics, 1, 85-92. DOI:10.29025/2079-6021-2019-1-85-92

Chilton, P. (2004). Analysing Political Discourse: Theory and Practice. New York: Routledge. DOI: $10.4324 / 9780203561218$

Dijk, van T. (1997). Discourse as Structure and Process: Discourse Studies a Multidisciplinary Introduction. L.: SAGE Publication Ltd.

Dobrosklonskaya, T.G. (2005). Issues of studying media-texts: Experience of research of modern English media-speech.

Dobrosklonskaya, T.G. (2008). Media Linguistics: a Systematic Approach to the Study of Media Language. Moscow, Flinta-Nauka.

Dolzhikova, S.N. (2009). Linguistic Aspect of Advertising. The Bulletin of Adyghe State University: Linguistics and Study of Arts, 2. Retrieved from: http://cyberleninka.ru/article/n/lingvisticheskiy-aspekt-reklamy (Accessed on October 13, 2015).

Franssila, S. (2013). Sell Metaphor in American Political News Discourse. Social and Behavioral Sciences, 95, 418-424. DOI:10.1016/j.sbspro.2013.10.664.

Jamieson, K.H., Campbell, K.K. (1997). The Interplay of Influence: News, Advertising, Politics and Mass Media. Belmont, Ca: Wadsworth Publishing Company.

Kazak M.Iu. (2011). Media Text: Essential and Typological Properties. Global Media Journal, 2(1). Retrieved from: http://test.gmj.sfedu.ru/v2i1/v2i1_kazak.htm

Tameryan, T.Yu., Zheltukhina, M.R., Slyshkin, G.G., Abakumova, O.B., Volskaya, N.N., Nikolaeva, A.V. (2018). Metaphor in Political Media Discourse: Mental Political Leader Portrait. Online Journal of Communication and Media Technologies, 8(4), 377-384. DOI:10.12973/ojcmt/3958.

Zelenskaya, L.L., Zubareva, T.T., Denisenko, V.N., Chervyakova, L.D., Kosova, Yu.A. (2018). Verbal Means of Media Manipulation with Fears (on Material of the American, English and Russian Tabloid Press). XLinguae, 11(3), 39-50. DOI:10.18355/XL.2018.11.03.04 
Dictum Factum

Zheltukhina, M.R. (2014). Media Impact on Consciousness and Behavior of the Addressee. The Bulletin of Center for International Education of Lomonosov Moscow State University. Philology. Culturology. Pedagogy. Methodology, (4), 65-73.

Zheltukhina, M.R., Bondareva, N.V., Zelenskaya, L.L., Anikeeva, I.G., Malygina, L.E., Chistyakov, A.V. (2019). Media Promotion Role of Economic Vocabulary: Specific Features and Functions in Presentation and Advertisement. Online Journal of Communication and Media Technologies, 9(2), e201907. DOI:10.29333/ojcmt/5733 